\title{
Intervention of ICTs in Rice Production in Bangladesh: An Impact Study
}

\author{
$\mathrm{S} \mathrm{Das}^{1 *}, \mathrm{M}$ N U Munshi², W Kabir ${ }^{3}$ and J K Biswas ${ }^{4}$
}

\begin{abstract}
Research led productivity gain in rice has enabled the growth of rice production. Organized research and extension played a great role in the success of rice development in the country. However, there exists scope for further yield gain through minimizing gap between research and farm. Information Communication Technology (ICT) has proved to be significant to enhance agricultural production. Realizing its potential, Bangladesh has currently started using ICT for its agricultural development programmes. The study has revealed the strong relationship of rice production of the ICT farmers with that of non-ICT ones. DiD (Difference in Differences) model was used to analyze the comparison of rice production of two service areas. Recall method was used to collect the data. The result indicates that the production of Boro and T. Aman rice from ICT service areas has increased more than those of non-ICT areas. The counter factual outcome of DiD analysis reflects the perspective weaker treatment of non-ICT service area and stronger one of the ICT service area.
\end{abstract}

Key words: DiD, yield gap minimization, communication

\section{INTRODUCTION}

Rice is the staple food of the peoples of Bangladesh. Nearly $48 \%$ of rural employment is provided by rice in the country. Rice is grown on about 11.4 million hectares. This growth trend has remained almost stable over the past three decades. About $75 \%$ of the total cropped area and over $80 \%$ of the total irrigated area is planted to rice (BRKB, 2017). Thus, rice plays a vital role in the livelihood of the people of Bangladesh. Bangladesh Rice Research Institute (BRRI) maintains about 8,000 rice germplasm in the Genebank collected from different parts of the country. In addition, Bangladesh Institute of Nuclear Agriculture has been working in developing rice varieties. Agriculture is a dynamic economic sector in Bangladesh. It needs regular adaptation of new farm technologies in order to meet the growing demands of diversified food items and other related production inputs. Increasing agricultural production for burgeoning population is a major challenge for present agriculture. The production system is smallholder dominated with an average farm size of 0.6 hectares (BBS, 2009) and these small holding farmers need to intensify and diversify farming through acquiring adequate information and knowledge. Proper dissemination of information for agricultural and rural communities is a crucial task and is challenging. Dissemination of relevant information to the farming communities at the right time can facilitate the effective adoption of agricultural inputs, decision making on the markets and adoption of scientific methods (Kiplang et al., 1999). Improvement of agricultural production, profitability and sustainability depends on the farmers to adopt change and their innovative use of technologies and availability of resources. Access, efficiency and affordability of agricultural information are the major barriers in the battle to uplift agricultural productivity among small scale farmers (Murithi et al., 2009). In Bangladesh,

\footnotetext{
${ }^{1}$ Senior Documentation Officer, Bangladesh Agricultural Research Council, ${ }^{2}$ Professor, Department of Information Science and Library Management, University of Dhaka; ${ }^{3}$ Former Executive Chairman, Bangladesh Agricultural Research Council, Dhaka; ${ }^{4}$ Former Director General, Bangladesh Rice Research Institute. *Corresponding author's E-mail: susmitabarc@gmail.com.
} 
agricultural information services that are being provided by Government, NGO, private organizations, agricultural research organizations and advisory centers are increasingly involved in orienting services towards the specific needs of the rural service delivery.

Efficient farming is often congested due to the limited scope of access to the information and knowledge in an appropriate and timely manner. This congestion creates a gap between researchers and farming community. It is often called knowledge gap between researchers and farmers. The gap also hampers productivity, therefore, in reducing this gap, agricultural information service delivery assumes a greater role in enhancing productivity. In this field, Information and Communication Technology (ICT) would be the best way to make this service effective. Actually ICT is characterized by the acquisition, development, storage, use and sharing of information and knowledge (Kavulya, 2007). In the last decades, farmers have improved their productivity through introduction of ICT in farming by proper intervention of public and private organizations. Haq (2011) added that unprecedented advances are seen in ICT initiatives in agriculture and these help Bangladesh come out of chronic food deficit and become self-sufficient country in food.

Everywhere it is evident that ICTs have potential to enhance agricultural production through introduction of farm technologies. The use of ICT in Bangladesh Agriculture started since 2003 with the inception of 'Support to ICT Taskforce Programme' by the Ministry of Agriculture. It was the first initiative to set up an Agricultural Information System in Bangladesh. After that, Bangladesh has undertaken many initiatives in using ICT for its agricultural development programmes. These ICT based initiatives include Union Information Service Center (UISC), Agriculture Information Communication Centers (AICC), Farmers Information Advice Centers (FIAC), Community Radio, Social Networks, Rice Knowledge Bank and Mobile Apps. Those attempts have been initiated by the public and private organizations and many NGOs to accelerate the dissemination of appropriate technologies to reach the end users. A number of government organizations like Agriculture Information Service (AIS), Department of Agriculture Extension (DAE), Department of Livestock Service (DLS), Department of Fisheries (DoF), Department of Marketing (DOM), AIS, National Agricultural Research System (NARS) and NGO, private sector, public and private TV channels, Bangladesh Betar (National Radio) and Community Radios are engaged in improving farmers' livelihood by their programmes. In this field, DAE and AIS under the Ministry of Agriculture play an important role. DAE effectively started using ICT for delivering agricultural information services for the agriculture. So, it is evident that ICT based different initiatives have potential to change the production of various crops in Bangladesh including rice.

Rice (Oryza sativa) is the main cereal crop and it grows in all the three crop growing seasons round the year covering about $75 \%$ of the total cropped area (11.4 million hectares) in Bangladesh. In recent years, the country has not only earned self-sufficiency in rice production, but also it is gradually entering into the export regime (BER, 2005). Rice is grown both under rain fed and irrigated conditions. Now, irrigated Boro is becoming major rice production season in the country. Traditional practices, local varieties, low levels of inputs and management are associated with rain fed agriculture. In general, productivity is low, and year to year fluctuation in production is large.

BRRI maintains about 8,000 rice germplasm in the Genebank collected from different parts of the country. High yielding varieties cover about 75 percent of the total rice area. Rice production in Bangladesh has taken a significant momentum since 1990-91, especially during two phases, from 1996-97 to 2000-01 and from 2009-10 to 2013-14 (Fig. 1) (Kabir et al., 2015b). Improved variety including location specific and stress tolerant rice (varieties) alone was not enough to achieve the goal. Government's support in 
mechanization and irrigation, controlling fuel and fertilizer price hike, significant reduction of non-urea fertilizer, improved loan distribution system (policy to deposit directly into farmers' account), organized fertilizer supply, increased quality seed supply by public and private sectors etc. play very significant role. Last but not the least ICT also plays a considerable role in disseminating agricultural technology and knowledge.

The objective of this study is to understand how ICT plays its role in the development of agriculture in Bnagladesh.

\section{MATERIALS AND METHODS}

Few instruments for the data collection were employed in the study. The main instrument was taken as two sets of questionnaire for two groups of farmers. Formal and informal interviews were held to explore the views, experiences, beliefs and motivations of individual participants. Few Focus Group Discussions (FGDs) were conducted for generating information on collective views and the meanings that lie behind those views. Extensive field visits in the ICT and non-ICT areas were made. The population of the study comprises farmers from all over the country and it is categorized into two types- ICT supported farmers and non-ICT supported farmers. Simple Random Sampling (SRS) method was used in this study and the number of sample
SRS was 1990 (Tables 1 and 2). The study area comprises of two types of farmers- those of ICT based service centers like Agricultural Information Communication Centers (AICCs) Farmers Information and Advisory Centers (FIACs), Union Information Service Center (UISC), Community Radios, Krishi Radio, Plant doctor etc and traditional farmers who are not involved in the activities of those service centers. The service area covers $58.8 \%$ of ICT and $41.2 \%$ of non-ICT based respondents. Out of 1170 ICT based respondents, $56.41 \%$ were from AICCs, $18.12 \%$ from FIACs, $11 \%$ respondents from UISC and $8.72 \%$ from community radios and the rest of the respondents were from Krishi Radio, Plant Doctor etc (Table 3). The non-ICT respondents in the present study are the farmers who for their production and marketing do hardly use tools that are related to information communication technology.

Each of the selected 42 districts was visited in two subsequent years (2013 and 2014) for data collection. For random sample sampling, the surveyed areas were unequal. Of these areas, Sylhet Division $(21.34 \%)$ is the highest responding area in the non-ICT service area. Khulna is the second highest representing $18.29 \%$ of 820 respondents. Chittagong is the lowest responding area where only $7.32 \%$ of the respondents were collected. Rajshahi and Rangpur having equal number of respondents $(12.80 \%)$ are outnumbered by Dhaka $16.46 \%$. Barisal is between the two, having $10.98 \%$ of the non-ICT respondents.

Table 1. Yield gap of rice 2008-2010 ( $\left.\mathrm{t} \mathrm{ha}^{-1}\right)$.

\begin{tabular}{|c|c|c|c|c|}
\hline Crop & Potential yield at research & Demonstration & Farmers' practice & Yield gap \\
\hline Aus rice & 9.00 & 4.85 & 3.50 & 1.35 \\
\hline Aman rice & 9.00 & 7.05 & 4.00 & 3.05 \\
\hline Boro rice & 9.00 & 7.85 & 4.80 & 3.05 \\
\hline
\end{tabular}

Table 2. Rice production (In lakh MT).

\begin{tabular}{lccccccccc}
\hline $\begin{array}{l}\text { Rice } \\
\text { grain }\end{array}$ & $2006-07$ & $2007-08$ & $2008-09$ & $2009-10$ & $2010-11$ & $2011-12$ & $2012-13$ & $2013-14$ & $\begin{array}{c}2014-15 \\
(\text { Target })\end{array}$ \\
\hline Aus & 15.12 & 22.93 & 21.00 & 21.33 & 23.33 & 23.32 & 21.58 & 23.26 \\
Aman & 108.41 & 1110.2 & 122.25 & 127.91 & 127.98 & 128.98 & 128.97 & 130.23 & 131.90 \\
Boro & 159.90 & 186.77 & 182.87 & 185.25 & 186.17 & 187.59 & 187.78 & 190.07 & 189.77 \\
Total & 283.43 & 319.76 & 326.12 & 334.03 & 335.41 & 338.90 & 338.33 & 343.56 & 388.95 \\
\hline
\end{tabular}

Source: Bangladesh Economic Review 2015. 
Table 3. Frequency distribution of ICT center respondents.

\begin{tabular}{lcc}
\hline ICT based Service & Respondent & Percent \\
\hline AICC & 660 & 56.41 \\
FIAC & 212 & 18.12 \\
UISC & 128 & 10.94 \\
Community Radio & 102 & 8.72 \\
Agricultural (Krishi) Radio & 20 & 1.71 \\
Others (Private initiatives) & 48 & 4.10 \\
Total & 1170 & 100.00 \\
\hline
\end{tabular}

Source: Author Survey 2013-2014.

The statistical package SPSS, DiD model and another statistical technique were used in econometric and qualitative sociology through experimental research design using observational study data were used to compare the production of two service areas as counterfactual condition. DiD calculates the effect of a treatment (an independent variable) on an outcome (dependent variable) by comparing the average change over time in the outcome variable for the treatment group to the average change over time for the control group. Reliability for internal consistency is calculated using the Cronbach's (1970) Alpha Coefficient.

\section{RESULTS AND DISCUSSION}

There are two periods- the baseline year and the follow-up year. The former is 2012 and the latter is 2014. Data were collected in 2014 from the farmers of two service areas by recall method. The product information about the past and the present was asserted by the respondents and the follow-up year is treated as the current year of the crop production whereas the baseline year is treated as the concurrent year. The production of Boro and T. Aman rice among different types of crops cultivated in three seasons in Bangladesh has been estimated in the section. The production of these crops is dependent variable that changes by the influence of ICT use in the cultivation process. The follow-up production of both groups has increased, but the rate of increase of ICT farmers is higher than that of non-ICT service areas.

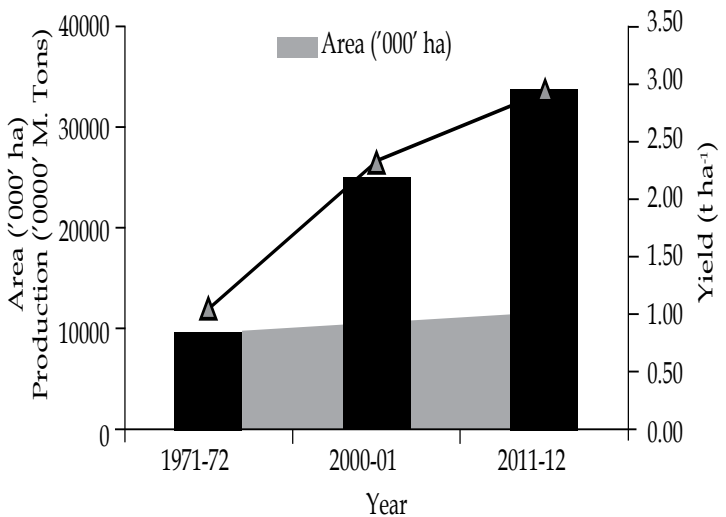

Fig. 1. Trend of production and yield of total rice (Source: BBS, 2013).

Figure 1 shows counterfactual condition that takes the generic form of difference of differences. The counterfactual marked green in the figure reveals the difference of rice production from non-ICT based service area that did not actually occur. It is argued here that such propositions play a necessary and fundamental role in the whole effects of ICT on a production system. Here it is found that the follow-up (2014) production of both ICT and non-ICT areas has gradually increased, but to a greater extent, the increase rate of the ICT service area is higher than that of non-ICT service area. Figure 2 indicates that the followup production of non-ICT based area is higher by 0.43 than that of baseline one (2012). Here it is seen that the baseline production of non-ICT 3.70 MT. and that of ICT and the counterfactual is $4.16 \mathrm{MT}$. The follow up of the counterfactual is $4.59 \mathrm{MT}$. but follow-up production of ICT is $5.07 \mathrm{MT}$. The degree of increase of ICT is so high that it exceeds to the counterfactual by 0.48 (5.07-4.59) as shown in the figure 2. Therefore, it is significantly proved that the Boro rice production from the ICT based service area has increased more than the increase of production of non-ICT based area.

Table 4 indicates that the counterfactual or potential outcome reflects the perspective weaker treatment of non-ICT service area and stronger treatment of the ICT service area. The follow-up production of ICT and non-ICT farmers is higher than that of the 
Table 4. Frequency distribution of non-ICT respondents.

\begin{tabular}{lcc}
\hline Division & Frequency & Percentage \\
\hline Barisal & 90 & 10.98 \\
Chittagong & 60 & 7.32 \\
Dhaka & 135 & 16.46 \\
Khulna & 150 & 18.29 \\
Rajshahi & 105 & 12.80 \\
Rangpur & 105 & 12.80 \\
Sylhet & 175 & 21.34 \\
Total & 820 & 100.00 \\
\hline
\end{tabular}

Source: Author Survey 2013-2014. baseline one. So the research result has proved that the use of ICT influences to increase the production of the farmers.

Figure 2 indicates that the degree of increase of ICT is higher and it exceeds to the counterfactual by 0.07 . The follow-up production of non-ICT based area is higher by 0.36 than that of baseline one (2012). Here it is seen that the baseline production of non-ICT $3.35 \mathrm{tha}^{-1}$ and that of ICT and the counterfactual is $3.67 \mathrm{tha}^{-1}$. The follow up of the counterfactual is $4.03 \mathrm{t} \mathrm{ha}^{-1}$ but follow-up production of ICT is a little bit higher by $0.07 \mathrm{t} \mathrm{ha}^{-1}$. Therefore, it

Table 5. Production performance of Boro (rice) by baseline and follow-up.

\begin{tabular}{|c|c|c|c|c|}
\hline \multirow{2}{*}{ Parameter } & \multicolumn{2}{|c|}{ Unstandardized coefficient } & \multirow{2}{*}{ T-value } & \multirow{2}{*}{ Sig. } \\
\hline & $\mathrm{B}$ & Std. error & & \\
\hline Constant & 3.70 & 0.09 & 41.04 & 0.00 \\
\hline Treatment & 0.46 & 0.08 & 5.64 & 0.00 \\
\hline Time & 0.43 & 0.09 & 4.66 & 0.00 \\
\hline Interaction between (Treatment $x$ Time) & 0.48 & 0.06 & 7.89 & 0.00 \\
\hline Dependent variable: yield of Boro rice $\left(\mathrm{t} \mathrm{ha}^{-1}\right)$ & & & & \\
\hline
\end{tabular}

Source: Author Survey 2013-2014.

Table 6. Production performance of T. Aman by baseline and follow-up

\begin{tabular}{|c|c|c|c|c|}
\hline Parameter & Unstandardized coefficient & Std. Error & T-value & Sig. \\
\hline Constant & 3.35 & 0.00 & $4,290.63$ & 0.000 \\
\hline Treatment & 0.32 & 0.00 & 322.71 & 0.000 \\
\hline Time & 0.36 & 0.00 & 332.50 & 0.000 \\
\hline $\begin{array}{l}\text { Dependent variable: } T \text {. Aman }\left(t \mathrm{ha}^{-1}\right) \\
\text { (Treatment } x \text { Time) }\end{array}$ & 0.07 & 0.00 & 53.19 & 0.000 \\
\hline
\end{tabular}

Source: Author Survey 2013-2014.

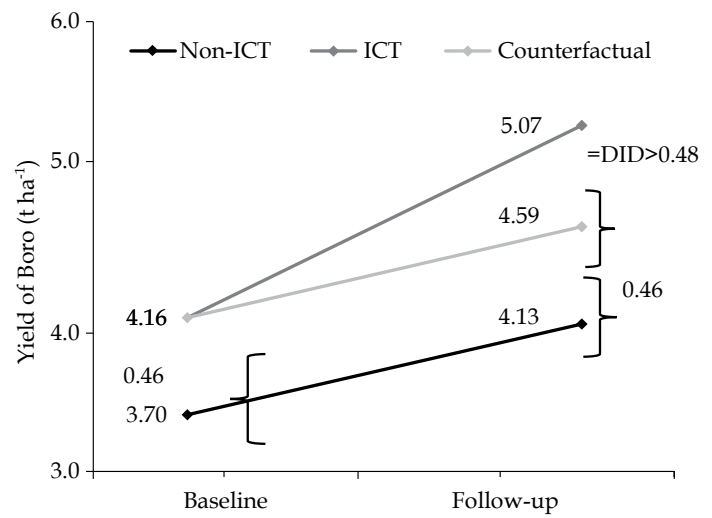

Fig. 2. Production performance of Boro rice by baseline and follow-up.

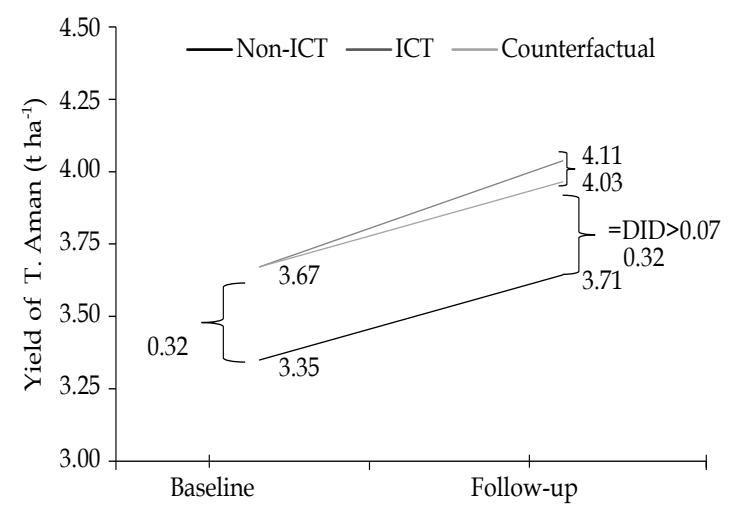

Fig. 3. Production performance of T. Aman by baseline and follow-up. 
is significantly proved that the T. Aman rice production from the ICT based service area has increased more than that of the production of non-ICT based area (Fig. 3).

Table 5 shows that the counterfactual or potential outcome reflects the comparative weaker treatment of non-ICT service area and stronger treatment of the ICT service area. The ICT follow-up production is higher (Table 6). So the findings reveal that the use of ICT has an obvious influences on the production increase of the farmers.

\section{CONCLUSION}

The study reveals that the research output achieved towards enhanced production can be successfully transmitted to the farmers using different modes of ICT tools. Public and private sector partnerships in disseminating the technological innovation may help enhance national level farm productivity of not only rice but other agricultural production. The extension of the present initiatives such as Agriculture Information Communication Centers, Farmers Information Advice Centers, Television and Radio Programmes, Community Radio, Social networks, Rice Knowledge Bank and Mobile apps could be the better parameters of the future production indicators and those may be managed with better organized manner. Besides, mobile based initiatives are the best suited ICT initiatives for quick delivery of information services. Involvement of expert services of those initiatives may benefit farmers in taking the right decisions to harvest higher return in agricultural practices. Designing appropriate networking among the different actors in the knowledge based ICT service centers may be developed through consultation with the research, extension and meteorological experts. A sustainable rural advisory service based business model may be worked out in continuation of the existing ICT hubs working in the country. Experiences of similar practices may be examined in the other rice growing countries.

\section{ACKNOWLEDGEMENTS}

Authors express sincere gratitude to the administrators of the CSISA-BARC Scholarship Programme for the fellowship grants to undertake this study as part of PhD programme.

\section{REFERENCES}

BER (Bangladesh Economic Review). 2015. Economic Advisor's Wing, Finance Division, Ministry of Finance, Government of People's Republic of Bangladesh, Bangladesh Secretariat, Bangladesh.

BBS (Bangladesh Bureau of Statistics). 2009. Statistical Pocketbook of Bangladesh 2008, Planning Division, Ministry of Planning, Government of People's Republic of Bangladesh, Sher-E-Bngla Nagar, Bangladesh.

BRKB. 2017. Bangladesh Rice Knowledge Bank. Retrieved from http://www.knowledgebank-brri.org/ riceinban.php

Haq, K M G. 2011. Information for rural development: Assessment of needs and designing a dissemination system for Bangladesh. Unpublished PhD Dissertation, University of Dhaka, Bangladesh.

Kabir, M S, M U Salam, A Chowdhury, N M F Rahman, K M Iftekharuddaula, M S Rahman, MH Rashid, S S Dipti, A Islam, M A Latif, A K M S Islam, M M Hossain, B Nessa, T H Ansari, M A Ali and J K Biswas. 2015. Rice Vision for Bangladesh: 2050 and Beyond. Bangladesh Rice J. 19(2): 1-18.

Kavulya, J M. 2007. Digital libraries and development in Sub-Saharan Africa: A review of challenges and strategies. The electronic library, 25(3): 299-315.

Kiplang, J. 1999. An analysis of the opportunities for information technology in improving access, transfer and the use of agricultural information in the rural areas in Kenya, Library Management, 20(2): 115-127.

Murithi, A G, E Bett, and S A Ogaleh. 2009. Information technology for agriculture and rural development in Africa: Experiences from Kenya. Paper presented at the conference on International research on Food Security, National Resources Management and Rural development, Tropetag: University of Hamburg, October 6-8 2009. 